\title{
Geleneksel ve Dijital Kitle İletişim Araçları Bakımından 1952 ve 2008 ABD Başkanlık Seçim Kampanyaları
}

\author{
MUSTAFA C. SADAKAOĞLU* \\ msadakoglu@gmail.com \\ ORCID ID: 0000-0002-4359-4828
}

\author{
ÖZGÜR EMEK KORKMAZ** \\ o.e.korkmaz@gmail.com \\ ORCID ID: 0000-0001-9934-4898
}

Öz: Modern birey, rızaya dayalı rejimlerin ortaya çıkışının ardından "seçmen" olarak tanımlanmış ve kullanıcısı olduğu kitle iletişim araçlarından yoğun olarak ikna edici siyasal iletişim mesajlarına maruz kalmıştır. Seçmenin maruz bırakıldığı mesajlar doğrultusunda tutum alması bakımından kitle iletişim araçları büyük önem taşımaktadır. Geleneksel kitle iletişim araçlarından dijital kitle iletişim araçlarına medya takip alışkanlıkları yıllar içinde değişse de medya ile demokrasi arasında var olan güçlü etkileşim aynı kalmaktadır. Günümüzde seçmenle kurulan ilişki bakımından siyasal aktörlerin gazete, radyo, televizyon gibi geleneksel kitle iletişim araçlarının yanı sıra çeşitli dijital iletişim araçlarını da yoğun olarak kullandığ gözlenmektedir. Bir seçim kampanyasında ilk kez televizyonun kullanılmış olması nedeniyle 1952 yılı ABD başkanlık seçimleri ile ilk kez bir dijital iletişim aracının kullanıldığı 2008 yılı ABD başkanlık seçimleri karşılıkl olarak incelenmeye olanak tanımaktadır. Bu maksatla medya ve demokrasi kavramları arasındaki etkileşim esas alınacak şekilde çalışmanın örneklemi olarak belirlenen seçim kampanyalarından elde edilen veriler incelenmektedir.

Anahtar kelimeler: Demokrasi, Siyasal iletişim, Siyasal reklam, Televizyon, Sosyal medya.

\section{Giriş}

18. yüzyılın son çeyreğinden itibaren artan endüstriyel üretimin kaynağında, Britanya'da başlayan ve zamanla etkinlik alanını genişleterek 19. yüzyıla evirilen Sanayi Devriminin güçlü etkileri bulunmaktadır. Modernleşme olarak da anılan bu süreçte üretim biçimiyle birlikte birey, toplum ve devletlerin ekonomik, siyasal ve kültürel düzlemde dönüştüğü bilinmektedir. ${ }^{1}$ Dolayısıyla modernleşme süreci, endüst-

\footnotetext{
* Dr. Öğr. Üyesi, İstanbul Aydın Üniversitesi, İletişim Fakültesi, Reklamcılık Bölümü.

** Yüksek Lisans Öğrencisi, İstanbul Aydın Üniversitesi, Sosyal Bilimler Enstitüsü, Halkla Ilişkiler Anabilim Dalı.

1 Marshall Berman modernleşme sürecini üç evre üzerinden bölümlemektedir. Buna göre modern hayat 16 ila 18. yüzyıllar arasını kapsayan evrede ilk kez deneyimlenmiştir. Bir tür şok hali nedeniyle modernleşmeye atfen dile getirilen karmaşa tanımlanamamış ve çözümü noktasında bir irade ortaya koyulamamıştır. Modernleşmenin ikinci evresi olarak gösterilen 18. ile 20. yüzyıl arasındaki dönemdeyse; 1776 yılında ilan edilen Amerika Birleşik Devletleri (ABD) bağımsızlık bildirgesi ile 1789 yılında gerçekleşen Fransız İhtilali ardından modern kamu ya da modern kamuoyu olarak adlandırılan kategoriler siyasal literatüre dahil edilmiştir. Marshall Berman, Katı Olan Her Şey Buharlaşıyor, çev., Ümit Altuğ ve Bülent Peker, İstanbul: İletişim Yayınları, 2017, s.29.
} 
riyel üretimin mükemmelleşmesi bakımından iktisadi, modern kamu ve kamuoyu kavramlarının gündelik hayata dâhil edilmesi bakımından siyasal olmak üzere iki alanda gerçekleşen bir dizi değişime tekabül etmektedir. Üretim ilişkileri ve kuşatıcı çalışma etiği bakımından aklileşmeyle kendini hissettiren modernleşme sürecinde gerçekleşen kitlesel göçler, hızlı kentleşme ve demografik yığışmalar nedeniyle gündelik hayat geri dönüşü imkânsız bir şekilde dönüşmüştür. Süreç içinde, geleneksel olarak yüz yüze iletişim yerine kitle basını aracıllğıyla giderilen iletişim ihtiyacının bir sonucu olarak ortaya çıkan kitle toplumu ve onun yeni tüketim anlayışı yanı sıra ihtilaller ve politik çalkantıların neden olduğu köklü siyasal değişimler yaşanmıştır. Modernleşme öncesi ekonomik örgütlenme bakımından merkezi önem taşıyan toprağa dayalı üretim biçimleri, modernleşme sonrası yerini fabrikalara ve kitlesel üretime bırakırken; yoğun ve hızlı sanayileşmenin neden olduğu kitlesel göçlerin etkisiyle geleneksel yaşam biçimlerinin yerini kentin yabancılaşmış ve izole yaşam biçimleri almıştır. Modernleşme deneyimi yeni bir yaşam biçimine geçiş bakımından zorlayıcı doğasıyla öne çıkmaktadır. Bu deneyim, her ne kadar öngörülemez bir gelecek tasavvuru dahilinde karmaşa ve kaostan beslenen tekinsiz bir yaşama tekabül ediyor olsa da üretim biçimi ve ekonomik örgütlenme bakımından yeniliğe, değişime ve dönüşüme açı "yeni bir insan”2 tipinin omuzları üzerinde yükselmektedir. Max Weber tarafından kavrandığı şekliyle modernleşmenin tezahürü olarak yeni insan, kapitalist üretim ilişkilerinin doğasını belirlemekle kalmayarak çok daha geniş bir perspektifle tarif edilmesi gereken modern kültüre özgü aklileşmenin bir sonucu olarak ortaya çıkmaktadır. Aklileşmenin başlangıç noktasında dinin rasyonel temellere oturtulmasıyla tamamlanan kilisenin dönüsserek Katolik eğilimlerin Protestan eğilimlerle yer değiştirmesi bulunmaktadır. Böylece üretim etiği ve iktisadî gelişme için ihtiyaç duyulan ruh, Protestan eğilimlerde somutlaşan fiili durumdan beslenebilmiştir. Kapitalizmin özü (ruhu) olarak işaret edilen Protestan etiğin kuşatıcı atmosferinde; üretim biçimiyle birlikte bilim, kültür, sanat, edebi üretim ve hukuk gibi uygarlığa içkin genel eğilimler de aklileşebilmiştir. ${ }^{3}$

Bilimsel bilginin üretime uygulanmasıyla ortaya çıkan fiili durum ve üretim biçiminin yetkinleşerek kitlesel üretim olanaklarının artmasıyla birlikte tüketim olgusu modern toplumların başat öğesi haline gelmiştir. Teknik olanakların üretim, ulaşım ve iletişim alanlarında uygulamaya koyduğu yenilikler toplumsal yapıyı dönüştürürken; sıradan insanın siyasal ve ekonomik alana daha fazla nüfuz etmesine imkân verecek şekilde rızası alınması gereken bir mercii olarak -siyasal özne ve kurumlar üzerinde- etki ve hakkının teslim edilmesine cevaz vermiştir. Bireyin ikna edilmesini esas alan iletişim formlarının odağında yer alan siyasal iletişim -ya da propaganda ve siyasal reklam- çabaları kitle iletişim araçlarıyla paydaşlığını arttırmıştır. 20. yüzyıl, kitle iletişim araçlarının birey üzerinde bıraktığı etkinin rasyonel düzlemde farkına varıldığı ve büyük bir iştahla kullanıldığı yeni bir dönemin kapılarını aralamıştır. $\mathrm{Bu}$

2 Max Weber tarafından modernleşme ve kapitalizme özgü yeni insan; doymak bilmez kar güdüsüne sahip, sınırsız kazanç arzusuyla yanıp tutuşan ve açgözlülüğü yüzünden gözleri kör olmuş irrasyonel bir tip olarak tarif edilmez. Aksine girişimci olarak tarif edilen yeni insanın dengeli ve rasyonel nitelikleri öne çlkarılır. Benzer şekilde bilimsel bilginin üretime uygulandığı haliyle teknoloji kavramı bütünüyle aklileşmeye tekabül etmektedir. Max Weber, Protestan Ahlakı ve Kapitalizmin Ruhu, çev., Mehmet Ökten, Ankara: Tutku Yayınevi, 2014, s.49-57. 3 Sabri Fehmi Ülgener, Zihniyet ve Din, İstanbul: Der Yayınları, 1981, s.17. 
nedenle 20. yüzyıldan itibaren kitle iletişim araçlarının vesile olmadığı başarılı olabilmiş herhangi bir ikna edici iletişim çalışması bulmak güçtür.

Çalışmada "medya ve demokrasi” arasındaki ilişki, 20. yüzyılın ikinci yarısından günümüze evirilen süreçte kitle iletişim araçlarının seçmen davranışları üzerinde bıraktığı güçlü etkilerin farkına varılarak yoğun bir şekilde kullanıldığı haliyle ele alınmaktadır. Bu maksatla 1952 yılı ABD Başkanlık seçimleri ve seçimlerde Dwight D. Eisenhower'ın liderlik ettiği seçim kampanyasında televizyonun kullanılması çalışmanın birinci örneklemini oluşturmaktadır. Diğer yandan Barack H. Obama’nın liderlik ettiği 2008 yılı ABD Başkanlık seçimlerinde ilk kez oy kullanacak genç seçmenler üzerinde etkinlik kurmak maksadıyla dijital iletişim platformu Facebook'un kullanılması çalışmanın ikinci örneklemini oluşturmaktadır. Dolayısıyla ilk kez televizyonun kullanılmasıyla ayırt edici öneme sahip olan 1952 yılı ABD Başkanlık seçimleri ile bir dijital iletişim platformunun yoğun bir şekilde ilk kez kullanıldığ 2008 yılı ABD başkanlık seçimleri karşılıklı incelemeye olanak tanıyan özellikleri nedeniyle çalışmanın iki örneklemini oluşturmaktadır. Böylece seçmen ile siyasal aktör arasındaki etkileşim değişen kitle iletişim deneyimi odağa alınarak açıklanmakta ve bu sayede medya ile demokrasi arasındaki ilişkinin açıklanması amaçlanmaktadır.

\section{Modernleşme ve İletişim Deneyimi}

Modernleşmeye ilişkin yapılan tanımlar birbirlerinden farklılık göstermektedir. Sözgelimi Emre Kongar’a göre modernleşme, ekonomi ve kültürle beraber toplumsal yapının, teknolojik gelişmeler ve sanayileşmenin etkisi altına girecek şekilde yeniden planlanması anlamına gelmektedir. ${ }^{4}$ Anthony Giddens modernleşmeyi, 17. yüzyıldan itibaren Avrupa'da beliren ve ardından bütün dünyayı etkileyecek şekilde yaygınlık gösteren yeni bir toplumsal örgütlenme biçimi olarak kavramaktadır. ${ }^{5}$ Modernleşme; ekonomik, siyasal ve kültürel alanlarda güçlü bir şeklide kendini hissettiren, önceki yıllarda görülmemiş biçimde etkili olmuş sarsıcı değişim ve dönüşümler şeklinde tarif edilebilir. Diğer yandan böylesine önemli bir konuda kronoloji belirlemek ve değerlendirme yapabilmek için tekil bir olaya odaklanmak yanıltıcı olabilir. Zira 18. yüzyılın ikinci yarısından itibaren Batı modernleşmesini hızlandıran Sanayi Devrimi, Britanya Demokratik Restorasyonu, ABD Bağımsızlık Savaşı ve Fransız İhtilali gibi bir dizi gelişme, modernleşme sürecinin derinliği ve yönü üzerinde kolektif katkıya sahiptir. Bu minvalde endüstriyel üretim öncesi geleneksel toplumları tanımlayan betimleyici tablonun odağında kırsal alanda yürütülen ve tarımsal üretime dayanan dar ve dışa kapalı bir ekonomik örgütlenme biçimi bulunmaktadır. Tarımsal üretime dayalı üretim kol gücüne dayanmakta, sermaye birikimine ihtiyaç duymamakta ve üretim sürecinde kullanılan aletler bakımından çok daha ilkel bir görünüm arz etmektedir. ${ }^{6}$

Demografik açıdan bakıldığında sanayi öncesi kırsal bölgelerde yaşayan insan toplulukları nüfus yoğunluğu açısından dünyanın en kalabalık yerleşim yerleri olma-

4 Emre Kongar, Toplumsal Değişme Kuramları, İstanbul: Remzi Kitabevi, 1981, s.229.

5 Anthony Giddens, Modernliğin Sonuçları, çev., Ersin Kuşdil, İstanbul: Ayrıntı Yayınları, 2018, s.9.

6 Richard H. Hall, Sociology of Work, California: A Sage Publications Company, 1994, s.76. 
larına rağmen liman kentlerinde kurulu fabrikaların artan iş gücü ihtiyacı nüfus hareketlerinin yönünü değiştirmiştir. Geç 18. yüzyıl ile 19 ve 20. yüzyıllar boyunca devam eden bu süreçte kırsal bölgelerde yaşayan insan toplulukları "daha iyi bir yaşam” vaadiyle kentlere akmıştır. Bu nedenle kitlesel göçlerin durmaksızın devam ettiği modernleşme sürecinin bir diğer belirleyeni baş döndürücü bir hızla büyüyen kentler ve giderek daha karmaşık hale gelen kent hayatıdır. ${ }^{7}$ Geleneksel yaşam pratikleri içinde yer alan yüz yüze iletişim deneyimi nedeniyle bu toplumlarda güçlü bir etkileşim söz konusudur ancak göç ettikleri kentlerin çeperlerinde kurulan sağlıksız alanlarda barınmak zorunda bırakılan kitleler geleneksel yaşam tarzlarını değiştirmek zorunda kalmıştır. Endüstriyel üretim ve hızlı kentleşme, ruhban ve aristokrasi ardından girişimci burjuva sınıfıyla geniş kalabalıklardan oluşan işçi sınıfının da bağımsız birer özne olarak siyasal yaşamda yer alabilmesinin önünü açmıştır. ${ }^{8}$

\section{İkna Edici İletişim ve Siyasal Reklamcılık}

Yarattığı siyasal sonuçlar bakımından modernleşme, ulus devlet ve yurttaş kavramının yoğun olarak tartışıldığı bir döneme tekabül etmektedir. Yurttaş, sorumlu olduğu topluma karşı ödevlerini yerini getiren, toplumsal çıkarları, kişisel çıkarlarının üzerinde tutabilen ve toplumun genel iradesi karşısında bireysel iradesini baskılayabilecek denli olgunluğa ulaşabilmiş bireydir. Bireysel çıkarlarını toplumun yararına baskılayan yurttaş yaklaşımında "toplumsal bilince erişmiş birey" ${ }^{9}$ aracılığıyla

\footnotetext{
7 Bu dönemde kentlerde gözlenen demografik yığışmanın boyutları benzersiz, etkileriyse sarsıcıdır. Sözgelimi, Almanya’nın 1871 yılında nüfusu yüz binden fazla olan 8 tane kenti varken, bu sayı 1900 yılında 33'e, 1910'da ise 48’e yükselmiştir. Rusya'da ise benzer nitelikteki kentlerin sayısı 1871 yılında 6 iken 1900 yılında 17’ye yükselmiştir. Aynı yılda, dünya nüfusunda 1 milyondan fazla olan Avrupalı kentler Paris ve Londra’yken 1900 yılında bu kentlere Berlin, Viyana, St. Petersburg, New York, Chicago, Philadelphia, Tokyo, Kalküta ve Osaka eklenmiştir; Ayrıntı için bkz. Oral Sander, Siyasi Tarih, İstanbul: İmge Yayınevi, 2001, s.215-216. Diğer yandan kentlerde biriken nüfus yoğunlukları üretimin ana parçası olmakla birlikte, biriken sermayenin fazla üretimini satın alacak bir tüketici durumuna gelmiştir. Sanayi öncesi geleneksel toplumlarda tüketim, ihtiyaç olanın karşılanması olarak ifade edilirken kent toplumlarında tüketim, bireyin kendini ifade biçimi, farklı olma, toplumsal bir statü arayışı, prestijli olma halini almıştır. Tüketim toplumu, medyadan kendisine bir gösteri şeklinde gösterilen bilgiyi de tam anlamıla beraber tüketen kitlelerden meydana gelmektedir. Bireyler ise tüketim sonucunda tekrardan anlam üretmezler, çünkü bu yeteneklerini yabancılaşma yüzünden kaybetmişlerdir; Ayrıntı için bkz. Erhan Atiker, Modernizm ve Kitle Toplumu, Ankara: Vadi Yayınları, 1998, s.67.

8 Sanayi devrimi aynı zamanda sarsıcı çalışma etiği bağlamında kendini hissettirmiştir. Girişimci kapitalizmin örgütlenmesini tamamlayarak güçlü etkiler gösterdiği bu dönemde; devasa üretim mekanizmasının birer parçası haline gelen kitlelere ilişkin kimi korku ve kaygılar da görünür hale gelmiştir. Kentlerde yaşayan kitleler, dönemin siyasal ve ekonomik seçkinleri tarafından ne yapacağı kestirilemeyen, amaçsız ve yön verilmesi gereken kalabalıklar olarak görülmektedir; Ayrıntı için bkz. Berman, Katı Olan, s.45-46. Bu dönemde işçi sınıfı girişimci kapitalizmin toplumsal yaşamı kuşatan güçlü etkileri nedeniyle daha çok kitle toplumu görünümündedir; Ayrıntı için bkz. Karl Marx ve Friedrich Engels, Komünist Manifesto, çev., Levent Kavas, İstanbul: İthaki Yayınları, 2011, s.85.

9 Sözgelimi 20. yüzyılın ikinci yarısından itibaren etkili olan "kullanımlar ve doyumlar” yaklaşımı; toplumsallaşmış bireye atfen tanımlanan ihtiyaç hiyerarşisi, kimi ihtiyaçların kitle iletişim araçlarıyla doyuma ulaştığ fikrinden temellenmektedir. Amerikalı psikolog Abraham Harold Maslow (1908-1970) tarafından insan doğasını anlamak gibi oldukça iddialı bir amaçla ortaya konan "ihtiyaçlar hiyerarşisi” adlı teoride; bireyin cinsellik, yemek yeme ve uyuma gibi fizyolojik, emniyette hissetme gibi güvenlik ihtiyaçları ve çevresiyle kurduğu ilişkilerde sevgi, saygı ve değer görme gibi aidiyet ihtiyacı ile kişisel başarı ve tatmin gibi kendini gerçekleştirme arzuları birbirleriyle bağlantılıdır; Ayrıntı için bkz. Henry David Thoreau, Walden and Other Writings, New York: Bantham Books, 1962. Diğer yandan modern dönemden günümüzde izole bir hayat yaşayan bireyler iletişim ihtiyaçlarını karşılamak için kitle iletişim araçlarını kullanmaktadırlar; Ayrıntı için bkz. Ruhdan Uzun, İletişim Kuramları, Erkan Yüksel, Eskişehir: Anadolu Üniversitesi Yayınları, 2013, s.89-90. Burada belirleyici olansa bireyin kitle
} 
kitleleri bir arada tutma istenci bulunmaktadır. ${ }^{10} \mathrm{Bu}$ minvalde ikna kavramı önem kazanmaktadır. İkna; belirli koşullar altında insani tutum ve davranışları değiştirmekle ilgilidir. ${ }^{11}$ Bireyin inanç ve değerlerini ya da herhangi bir konuda sahip olduğu tutumları değiştirmek maksadıyla önceden tasarlanmış iletişim eylemi olarak ikna sürecini başlatan kaynak bakımından sürecin yürütüleceği kanal ile sürecin hedefi olan alıcının içinde bulunduğu koşullar önem kazanmaktadır. ${ }^{12}$ Kaynak tarafından dolaşıma sokulan ikna içeren mesajın, önceden belirlenmiş hedef ve amaçlarla belli bir program dâhilinde kurgulanması gerekmektedir. İkna edici iletişim sürecinin kurgusu tesadüflere bırakılamayacağı gibi alıcıya yönelik zorlayıcı bir dil ya da üslup içermemelidir. Bu nedenle ikna; kaynak tarafından belirlendiği şekliyle hedefin tutum ve davranışlarını belirli bir plan dâhilinde önceden belirlenmiş amaçlara yönelik değiştirmek, dönüştürmek ya da pekiştirmek maksadıyla gösterilen bilinçli çaba olarak tanımlanabilir.

Tarihi Antik Yunan'a dayanan ikna konusunu -gündelik hayatın pek çok alanında geçerli olacak şekilde sözgelimi mahkemelerde ve pazar yerlerinde- gözlem yaparak inceleyen ve bu yönüyle çağdaş iknanın temellerini oluşturan önemli araştırmacılardan biri olarak kabul edilen Aristoteles'in dört yüzden fazla sayıda çalışması ortaya çıkarılmıştır. Aristoteles, özellikle "Retorik” adlı eserinde ikna kavramına ilişkin teoriler ortaya koymuş ve ikna edici iletişimin tanımlanması bakımından modern reklamcılık uygulamalarında dahi gözlenen uzun süreli etkilerde bulunmuştur. ${ }^{13}$ Hocası Platon'dan farklı olarak retorik ile diyalektik kavramını aynı düzlemde kavramakta sakınca görmeyen Aristoteles, bir gösteri olarak tanımladığı "kanıtlarla inandırma"14 eylemini retorik sanatının esası olarak kabul etmektedir. Oysa retorik, inançlarla ilgili olması bakımından diyalektikten farklıdır ve daha çok "pistis" kavramıyla karşılanan bir dizi inançla ilgilidir. Diyalektik ise "episteme" adı verilen bilgiye ve kanıtlamaya dayanmaktadır. ${ }^{15}$ Bilgiyi odağa alan diyalektik, öğretme amacı taşırken; esasında doğru bilgi olmadığı halde hatip adı verilen hitabet üstatlarının amacı dinleyicilere bir şeyler öğretmekten ziyade dinleyiciler üzerinde arzu edilen sanıyı oldurmaktır.

iletişim araçlarını, kendi isteği doğrultusunda kullanıp kullanamayacağıdır. İzleyici gerek araç seçiminde gerekse iletişim sürecinde gereksinimlerini gidermek için başlatıcı rolündedir. Bu yaklaşım, kitle iletişim araçlarının tutum ve davranışlara olan doğrudan etkisine bir sınırlama getirmektedir. Oysa "etki” kavramı yanlış yöne doğru sürükleyicidir ve kullanımlar ve doyumlar yaklaşımına göre televizyon izleyicileri kullanmaz aksine izleyiciler televizyonu kullanmaktadır. Bu durum kitle iletişim sürecinin toplumsal bağlamdan bağımsız ele alınamayacağını göstermektedir; Ayrıntı için bkz. İrfan Erdoğan ve Korkmaz Alemdar, Öteki Kuram, Ankara: Erk Yayıncilık, 2005, s.164-168.

10 Filiz Aydoğan, “Tüketim Kültürünün Gölgesinde Kentler”, Marmara Üniversitesi İktisadi ve İdari Bilimler Dergisi, 27/2 (2009), s.207.

11 Daniel J. O’Keefe, Persuasion: TheoryerResearch, California: Sage Publications, 2002; Richard M. Perloff, The Dynamics of Persuasion, New Jersey: Lawrance Erlbaum, 2010; James Price Dillard ve Lijiang Shen, The Sage Handbook of Persuasion, California: Sage Publications, 2012.

12 Jean G. Jones ve Herbert W. Simons, Persuasion in Society, New York: Routledge, 2017, s.23.

13 Aristoteles, Retorik, çev., Mehmet H. Doğan, İstanbul: Yapı Kredi Yayınları, 1995, s.19-21.

14 Diğer yandan Platon "Gorgias" diyaloğunda retoriğin bir sanat olduğu kabulünden hareketle amacının ne olduğuna ilişkin soruyu "amacını sözlerle gerçekleştiren, kendi konularıyla alakalı eğitim veren bir sanat dalı" olarak cevaplamaktadır. Buna göre sadece söze dayanan bir sanat olarak retorik kalabalıkları (kimi zamansa yargıçları, meclis üyelerini ve yurttaş toplantılarında bulunanları) ikna etmekte kullanılan bir inandırma sanatıdır; Ayrıntı için bkz. Platon, Gorgias, çev., Reyan Erben, İstanbul: M.E.B. Yayınları, 1997, s.352-E, 449-E, 453-E. 15 Platon, Gorgias, s.201-A,454-D. 
Aristoteles; "artistik kanıtlar" ile "artistik olmayan kanıtlar" şeklindeki ikili ayrım üzerinden ikna olgusunu tartışmaktadır. Artistik kanıtlar ikna edicinin fiziksel özelliklerine, yaratıcılığına ve iletişim ortamının özelliklerine tekabül etmektedir. Buna göre ethos; fiziksel kanıtlara dayanmakta ve itibar ya da kişisel karizma gibi özelliklerle ilgilidir. Sözgelimi hatip (kaynak), dinleyicilerin (hedef ya da alıcı) tanımadığı yabancı bir kimse bile olsa kullanacağı doğru jest ve mimikler sayesinde ikna edici etki yaratabilir. Dahası ikna edici olarak hatibin alanında uzman olması, sahip olduğu deneyimler ve dürüstlüğü ikna ediciliğine katkıda bulunabilir. Hatibin kullandığı dil, jest ve mimikler ile meselesini ele alırken seçtiği terim ve kavramların yanı sıra ses tonunu doğru ayarlaması dinleyicilerin ikna edilmesini kolaylaştırmaktadır. Pathos olarak tanımlanan özel durum hatip ile dinleyicilerin içinde bulunduğu duygusal atmosferi tanımlamakta kullanılmaktadır. İkna edici iletişimin başarısı, dinleyicilerin duygu durumlarının doğru tespit edilmesine ve bu tespit doğrultusunda ortaya konacak artistik kanıtların geliştirilmesine bağlanmaktadır. Son olarak logos, hatip ve dinleyiciden oluşan tarafların aklileşmesi ve ele alınan olguların rasyonel bir şekilde dile getirilmesiyle ilgilidir. Buna göre hatip, dinleyicilerin bilgilenmesiyle tamamlanacak ikna edici iletişim sürecini rasyonel olarak planlayabilmeli, buna göre argümanlar ortaya koyabilmeli ve dinleyicilerin nasıl karar vereceklerini tahmin edebilmelidir. ${ }^{16}$

Platon ve Aristoteles'in retorik yaklaşımı bağlamında ikna edici iletişim sürecinin nasıl işletilmesi gerektiğine ilişkin öngörüler, modern ticari reklamcılıkta olduğu gibi siyasal reklamcılık faaliyetlerinde de kullanılmaktadır. En yalın haliyle bir ürün ya da hizmetin satışını gerçekleştirmek üzere kurgulanan mesajların kitle iletişim araçları vasıtasıyla iletilmesi olarak tanımlanan ticari reklamcılık ile siyasal aktörlerin; parti, aday ya da ideolojileri üzerinden seçmen davranışları üzerinde etkili olmak amacıyla gerçekleştirdikleri siyasal reklamcılık benzer şekilde ikna olgusuna dayanmaktadır. Siyasal reklamlar, siyasal parti ya da aktörler tarafından medyada yer ve zaman satın alınmasıyla gerçekleştirilen ve seçmenlerin oy verme davranışlarını arzu edilen yönde değiştirme, dönüştürme ya da pekiştirme amacıyla kurgulanan mesajların kitle iletişim araçları üzerinden yayınlanmasıyla ilgili ikna edici iletişim faaliyeti olarak tanımlanmaktadır. ${ }^{17}$ Reklam verenler tarafından ürün ya da hizmet satışını arttırmak maksadıyla gerçekleştirilen ticari reklamların görece uzun bir zaman diliminde yayınlanabilmesi mümkünken; siyasal reklamlar, sadece seçim dönemi öncesi bir ya da iki aylık periyodlarda hedef kitleye ulaştırılabilmektedir. Seçim yasalarında bulunan kimi yasal zorunluluklar bir yana bırakılırsa bunun en önemli nedeni, siyasal reklamların yayımlanmasının ardından kısa süre sonra gerçekleşecek seçimlerde oy verme davranışları üzerinde etkili olabilme gerekliliği bulunmaktadır.

Ürün ya da hizmet satışlarını arttırmaya yönelik kurgulanan ticari reklamlara göre çok daha kısıtlı zaman diliminde ve çok daha kısa süreli olarak yayımlanabilen siyasal reklamların kısıtlı bir zaman diliminde en fazla kişiye ulaşacak şekilde planlan-

16 Ahmet Haluk Yüksel, İkna Edici İletişim, haz., Mine Oyman, Eskişehir: Anadolu Üniversitesi Yayınları, 2014, s.21-23.

17 Ferruh Uztuğ, Siyasal Marka Seçim Kampanyaları ve Aday İmajı, Ankara: Mediacat Yayınları, 1999, s.122. 
ması gerekmektedir. Bu nedenle en etkili ve yaygın kullanım olanağı sunan kitle iletişim araçları daha çok tercih edilmektedir. Sözgelimi 20. yüzyılın ilk yarısında gazete ve radyonun egemen olduğu aracılanmış iletişim pratiği; yüzyılın ikinci yarısından itibaren yerini ağırlıklı olarak televizyona bırakmıştır. Modernleşme sürecinin bir tezahürü olarak aracılanmış iletişim deneyimi kentleşme ve kent kültürüyle ilgilidir. Hızlı kentleşme ve ürün niceliğinin artmasıyla birlikte fiyatları düşen gazetelerin daha fazla satın alınmasıyla başlayan bu süreçte, gazeteler okuyucu isteklerine göre biçim ve içeriklerinin değiştirirken; toplumsal yaşamdan giderek daha fazla soyutlanan modern birey kitle iletişim araçlarının etkisine daha açık hale gelmiştir. ${ }^{18} \mathrm{Bu}$ nedenle geçmişi 17. yüzyıla dayanan gazete yayıncılığının kitle yayıncılığına yönelerek kitle basını niteliği kazanması 19. yüzyılda gerçekleşen bir dizi modernleşme göstergelerine bağlanmaktadır. Sözgelimi Britanya'da ancak 1890’lı yıllarda bir ticari etkinlik alanı olarak yazılı basının gelir kaynakları çeşitlenebilmiş ve bir tür ticari basın ortaya çıkmıştır. Diğer yandan sinema 1910 ila 1920'li yıllarda popüler bir izlence haline gelirken; 1920'lerin ikinci yarısı itibariyle radyo yayınları süreklilik kazanarak kurumsallaşmıştır. Bu minvalde 1940'lı yıllarda televizyon gündelik hayatın bir parçası haline gelmiştir. ${ }^{19} \mathrm{Bu}$ doğrultuda siyasal parti ya da adayın seçmen nezdinde kabul görmesi maksadıyla yapılan tanıtım çalışmalarından oluşan siyasal reklamlar ikna edici iletişim tekniklerinden oluşmaktadır. ${ }^{20}$

Bu bağlamda siyasal reklamlar ile kitle iletişim araçları arasındaki ilişkinin başarısında dört temel gerekliliğe işaret edilmektedir: ${ }^{21}$

1. Toplum nezdinde ilgi ve dramatik etki yaratabilmeli.

2. Bilinen temalar üzerinde durulmalı; hikâyeler ile stiller birbirleriyle ilgili olmalı.

3. Siyasal aktörler ve liderler yerine sıradan insanlara odaklanmalı.

4. Mesajlar toplumun genelince anlaşılacak şekilde yalın ve basit olmalı.

\section{ABD-1952 Seçim Kampanyasında Televizyonun Kullanılması}

Amerika Birleşik Devletleri (ABD)'nde 1952 yılında gerçekleştirilen başkanlık seçimleri, ABD ile Sovyet Sosyalist Cumhuriyetler Birliği (SSCB) arasında gerçekleşen

18 Kitle iletişim araçlarının gücü; 1938 yılında ABD’de yayımlanan bir radyo programında "Dünyalar Savaşı" isimli radyo tiyatrosunun dinleyiciler nezdinde yarattığı etkiyle somutlaşacaktır. Orson Welles tarafından sunulan radyo tiyatrosunda anons edilen "Marslılar dünyaya ulaştı ve Amerika Birleşik Devletleri’ni istila ediyor" şeklindeki ifadeler, dinleyiciler üzerinde gerçek olay etkisi yaratmıştır. Her ne kadar programın bir radyo tiyatrosu ve H.G. Wells'e ait radyo tiyatrosuyla aynı adı taşıyan romandan bir bölüm olduğu ifade edilse de pek çok Amerikalı anonsu duyar duymaz panik içinde bulundukları bölgeden uzaklaşmaya çalışmıştır; Ayrıntı için bkz. Paul Heyer, The Medium and the Magician, Maryland: Rowman \& Littlefield Publishers, 2005, s.76. Yaşanan bu olay kite iletişim araçlarının insanlar üzerinde ne kadar etkili olduğunun anlaşılması açısından önemli olmuştur. Diğer yandan 1933 ila 1945 yılları arasında radyo, Nasyonal Sosyalist Alman İşçi Partisi ve Nazizm’in Almanya’da kurduğu totaliter iktidarında çok önemli rol oynamıştır. Naziler için radyo bir enformasyon aracı olması yanı sıra iktidarlarını pekiştirmek kullandıkları güçlü bir propaganda aracıdır aynı zamand; Ayrıntı için bkz. Gülcennet Öztürk, "Bir Propaganda Aracı Olarak Radyo", Abant Kültürel Araştırmalar Dergisi, 2/3 (2017), s.166. Benzer şekilde radyo 1923 yılından itibaren Britanya İşçi Partisi tarafından da bir propaganda aracı olarak kullanılmış ve bu sayede önemli başarılar elde etmiştir; Ayrıntı için bkz. Burcu Zeybek, Siyasal Reklam İkna ve Retorik, İstanbul: Beta Yayıncilik, 2016, s.116.

19 Levent Yaylagül, Kitle İletişim Kuramları, Ankara: Dipnot Yayınları, 2018, s.18.

20 Michel Bongrand, Politikada Pazarlama, çev., Fatoş Ersoy, İstanbul: İletişim Yayınları, 1992, s.17.

21 Darren G. Lilleker, Siyasal İletişim, çev, Könül Mammadlı, İstanbul: Kaknüs Yayınları, 2013, s.202 - 203. 
nükleer silahlanma yarışı ve iki kutuplu dünya gerginliğinin küresel düzlemde hissedildiği Soğuk Savaş dönemine tekabül etmektedir. 1952 yılında gerçekleştirilen seçimler; özgürlüklerin askıya alındığı, militarizmin yükselişe geçtiği, sinema ve basın üzerinde uygulanan sansür ve baskıların yoğunluk kazandığı bir atmosferde gerçekleştirilmiştir. Amerikan Senatosu'nda güç sahibi Wisconsin Senatörü Cumhuriyetçi Joseph Raymond McCarthy'nin (1908-1957) başını çektiği Amerikan toplumundan komünist casusları temizleme gayretkeşliğiyle zirveye ulaşan senato soruşturmalarında pek çok aydının toplumsal itibarları linç edilmiştir. ${ }^{22} 1952$ seçimleri; soğuk savaş, iki kutuplu dünya tahayyülü ve nükleer silahlanma yarışının kuşatıcı atmosferinde özgürlüklerin askıya alındığı bir ortamda gerçekleştirilmiştir.

Demokratların adayı güçlü bir hatip olarak tanınan Illinois Valisi Adlai Stevenson (1900-1965) ile Cumhuriyetçilerin adayı eski savaş kahramanı Dwight D. Eisenhower (1890-1969) 1952 Başkanlık seçimlerinde karşı karşıya gelmiştir. ${ }^{23}$ Seçimlerin öne çıkan bir diğer özelliği Beyaz Saray’ın 20 yıllık demokrat iktidarının test edilecek olmasıdır. Kampanya süreci profesyonel ajansların katkısıyla hazırlanan siyasal reklamların ilk kez televizyon kanalları aracılığıyla yayınlanması bakımından devrimci bir karaktere sahiptir. ${ }^{24}$ Zira cumhuriyetçi aday Eisenhower için reklam ajansıyla (Young\&Rubicam) anlaşılmış ve dönemin etkili reklamcılarından Rosser Reeves (1910-1984) kampanyanın yürütülmesinde önemli bir paya sahip olmuştur. Reeves, siyasal reklamların televizyon üzerinden yayınlanmasının seçim sonuçları üzerinde etkili olacağına inanan ve bu maksatla 30'ar saniyelik reklam spotlarıla seçmene hitap edilmesi gerektiğini savunan bir reklamcıdır. Televizyon, ikna edici siyasal reklam mesajlarının iletilmesinde dönemin en etkili, en hızlı ve en ucuz iletişim aracı olarak görülmektedir. Ancak kampanya planlaması sadece iletişim kanalının ve mesajın belirlenmesiyle sınırlı tutulmamalıdır. Eisenhower’ın fiziksel görüntüsünün çekimlerde nasıl daha iyi gösterilebileceği konusu da önemle ele alınmıştır. Dolayısıyla o güne kadar "ciddi bir uğraş" içindeki politik aktörlerin ekran dünyasının yazılı olmayan kurallarına uyması gerekmiştir. Bu maksatla eski savaş generali yeni başkan adayı Eisenhower’a seyrelmiş saçları nedeniyle ekranda gereğinden fazla eğilmekten kaçınması ya da daha iyi bir görüntü verebilmesi için gözlük takmaması gibi öne-

22 Amerikan Aleyhtarı Faaliyetleri İzleme Komitesi -The House Un-American Activities Committee-HUAC1938 yılından 1975 yılına kadar faaliyette bulunmuştur. Ancak özellikle 1950'li yıllarda Wisconsin Senatörü Joseph Raymond McCarthy'nin öne çıktığı soruşturmalarda pek çok oyuncu, yönetmen, senaryo yazarı ve set işçisinin de aralarında bulunduğu sinema emekçilerine yönelik uydurma delillere dayalı cezalar vermiştir. Mustafa C. Sadakaoğlu, "Yeni Türk Sinemasında Modern Melodram Geleneksel Söylem”, Motif Akademi Halkbilimi Dergisi, 12/28 (2019), s.1191.

23 Dwight David Eisenhower ABD’nin 1953-61 yılları arasında görev almış 34. Başkanıdır. Eisenhower, İkinci Dünya Savaşı esnasında Batı Avrupa Müttefik Ordularına, savaşın ardındansa Kuzey Atlantik Paktı (NATO) tarafından kurulan askeri kuvvetlere komuta etmiștir. Eisenhower'ın başkanlık dönemi soğuk savaşın en çetin dönemine tekabül etmektedir. Eisenhower eski bir savaş generali olmasına rağmen Kore'deki çatışmaları sona erdiren ateşkesi korumuş ancak soğuk savaş yıllarında SSCB’ye yönelik küresel düzlemde yürürlüğe konan bir dizi askeri, ekonomik ve kültürel baskı politikalarını devam ettirmiştir. Başkanlık döneminde savunma öncelikleri gerekçesiyle nükleer silah üretimi olanca hızıyla sürmüştür. Diğer yandan İran’ın ulusalcı politikalarıyla tanınan başbakanı Muhammed Musaddık’a karşı 1953 yılında yapılan darbeye destek vererek, yerine Şah Muhammed Rıza Pehlevi'nin getirilmesinde etkin rol oynamıştır.

24 Judith S. Trent ve Robert V. Friedenberg, Political Campaign Communication: Principles and Practices, London: Penguin Books, 2000, s.140. 
rilerde bulunulmuştur. Böylece siyasal alanda gösteri dünyası ile politik dünyanın birbirine yaklaştığı hatta zamanla benzeştiği yeni bir evreye geçilmiştir.

Kampanya için hazırlanan "Eisenhower Answers America-Eisenhower Amerika'yı Yanıtlıyor” başlıklı metinlerin yazarı Rosser Reeves, dönemin etkili araştırma şirketlerinden Gallup tarafından düzenlenen anketler aracılığıla toplanan bilgileri kullanarak üç önemli konuda -Kore savaşı, ekonomik sorunlar ve siyasi yolsuzluk iddiaları- Eisenhower'ın yaklaşımlarını içeren 30'ar saniyelik televizyon spotları hazırlamıştır. Televizyon spotları, seçmenden gelen sorular ile Eisenhower tarafından verilen samimi yanıtların stüdyo çekimleriyle birleştirilmesinden oluşmaktadır. Eisenhower'in gelen yazılı soruları yanıtlayarak seçmenlerine hitap ettiği reklamlar devrim niteliğindedir. Zira bir adayının alışıldığı üzere gereksiz pek çok konuyu içeren uzun ve sıkıcı konuşmalarla seçmene hitap etmesi yerine önemli olduğu önceden tespit edilen belirli konularda basit içerikler ve kısa tekrarlardan oluşan spotlarla bilgilendirme yapması çok daha yenilikçidir. ${ }^{25}$ Siyasal reklam stratejisinin motivasyonu kısa ancak sık tekrarlanan mesajlar kullanılarak seçmen zihninde çok daha kolay yer edinileceği yönündeki kabule dayanmaktadır. Eski bir savaş generali olarak Eisenhower'ı böylesine yenilikçi bir yaklaşımı kabul etmeye bizzat Reeves'in ikna ettiği iddia edilmektedir. ${ }^{26}$ Eisenhower kampanyası "I like IKE-Eisenhower's seviyorum” şeklinde başkan adayının kısa adını içeren oldukça samimi bir slogan eşliğinde yayınlanmıştır. Diğer yandan demokrat aday Stevenson adeta bir ürün reklamı yapar gibi başkan adaylarının televizyonlardan pazarlanmaması gerektiğine ilişkin ifadeleriyle oldukça katı bir tavır içerisinde kalmıştır. Kampanya sürecinde ülkenin en güçlü televizyon kuruluşlarından gelen ve her iki adayı ekranda tartışmaya çağıran davetler kabul görmemiştir. Eisenhower'in de daveti kabul etmemesine rağmen Stevenson'un siyasal reklamlara olan mesafesi nedeniyle ekranda başarısız olmaktan korktuğu şeklinde yorumlara neden olmuştur. Diğer yandan kampanya sürecinde yalnız olarak katıldığı televizyon programlarında Stevenson, çoğu kez zamanını iyi ayarlayamamış, kendisine tanınan süreyi aşmış ve yapımcılar tarafından sözleri yarida kesilmiştir.

Eski bir asker olarak başkan adayı Eisenhower’a gösterilen ilgi büyük oranda İkinci Dünya Savaşı́nda yaptı̆̆ı hizmetlerden kaynaklanmaktadır ancak Eisenhower'ın kampanya boyunca televizyon aracılığıyla verdiği mesajlar da seçmende karşılık bulmuştur. Eisenhower, gerek eski bir savaş kahramanı olması gerekse televizyon spotlarında gösterdiği başarılı performans nedeniyle seçmen nezdinde içten, dürüst ve açık sözlü bir başkan adayı izlenimi inşa edebilmiştir. Stevenson ise parlak zekâlı, ince, sevimli, açık sözlü ve dürüst bir politikacı olarak bilinmesine rağmen seçmene kendini ifade etmekte başarısız olmuştur.

25 John E. Hollitz, "Eisenhower and the Admen: The Television "Spot” Campaign of 1952", The Wisconsin Magazine of History, 66/1 (1982), s.31.

26 AdAge, "Reeves, Rosser (1910-1984)”, erişim 16 Nisan, 2020, https://adage.com/article/adage-encyclopedia/ reeves-rosser-1910-1984/98848. 
Tablo 1. Televizyon Spotlarında Kullanılan Seçili Soru, Cevap ve Göndermeler ${ }^{27}$

\begin{tabular}{|l|l|l|}
\hline Soru & Cevap & Gönderme \\
\hline $\begin{array}{l}\text { Demokratlar hata } \\
\text { yapmış olsalar da } \\
\text { iyi niyetli değiller } \\
\text { miydi? }\end{array}$ & $\begin{array}{l}\text { Evet ama öğrencileri taşıyan bir otobüs, } \\
\text { kamyona ya da elektrik direğine çarpar ve } \\
\text { şoför otobüsü çukura düşürürse iyi niyetli } \\
\text { olup olmadığını sormadan değiştirirsiniz. }\end{array}$ & $\begin{array}{l}\text { 1. Hayat Pahalılığı } \\
\text { 2. Yolsuzluklar } \\
\text { 3. Kore Savaşı }\end{array}$ \\
\hline $\begin{array}{l}\text { Bakkaldan birkaç } \\
\text { şey alabilmek için } \\
\text { 22 dolar ödedim. }\end{array}$ & $\begin{array}{l}\text { Doğrudur, birkaç yıl önce aynı öteberiyi 10 } \\
\text { dolara alabilirdiniz. Böyle giderse gelecek } \\
\text { yl 30 dolar ödeyeceksiniz. }\end{array}$ & $\begin{array}{l}\text { 1. Hayat Pahalılığı } \\
\text { 2. Yolsuzluklar }\end{array}$ \\
\hline $\begin{array}{l}\text { Yeni bir savaşa mı } m \\
\text { gireceğiz? }\end{array}$ & $\begin{array}{l}\text { Hayır, barışa iyi hazırlanırsak savaş olmaz. } \\
\text { Koreye tank ve uçak yollamak için yüzlerce } \\
\text { milyar dolar harcamayabiliriz. }\end{array}$ & $\begin{array}{l}\text { 1. Kore Savaşı } \\
\text { 2. Hayat Pahalılığı } \\
\text { 3. Yolsuzluklar }\end{array}$ \\
\hline
\end{tabular}

Sonuç olarak 1952 başkanlık seçimleriyle birlikte televizyon, Amerikan siyasal hayatını geriye dönülemeyecek denli derinden değiştirmiştir. 1952 seçimlerine kadar adaylar, önceden planlanan programlar dâhilinde büyük kentlerde katıldıkları açık hava mitingleri ya da salon toplantılarında seçmene hitap ederken; 1952 seçimleriyle birlikte sayılan faaliyetlere ek olarak televizyonlarından başkan adaylarını izleyen milyonlarca seçmene siyasal reklamlar aracılığıyla kendilerini ifade edebilmişlerdir. Diğer yandan Eisenhower'in seçimi kazanmasında tek etmen televizyon olmasa da kampanyanın başarısına olan katkısı büyük olmuştur.

\section{ABD-2008 Seçim Kampanyasında Yeni Bir İletişim Mecrası Olarak Facebook'un Kullanılması}

2008 yılı ABD başkanlık seçimlerinde Demokrat aday Barack H. Obama kampanya stratejisini genç seçmenleri dışarıda bırakmayacak şekilde kurgulamıştır. Genç seçmenlerin televizyon izlemek, radyo dinlemek ya da gazete okumak yerine dijital iletişim araçlarını kullanarak iletişim içinde olduğu yeniçağda siyasal kampanya stratejilerinin de yenilenmesi önemli bir gerekliliktir. Bu maksatla "Facebook" adlı sosyal paylaşım ağının kurucularından Chris Hughes, kampanyanın "online-çevrimiçi” direktörü olarak atanmıştır. Kampanya direktörü olarak atanmasının ardından Hughes'un ilk işi, Obama’nın "barackobama.com" adlı web sitesini yeniden düzenlemek ve "mybarackobama.com" adıyla yenilenen web sitesini, kullanıcıların içerik üretebildiği ve ürettikleri içerikleri paylaşabildiği yeni bir mecraya çevirmek olmuştur. Bu sayede çoğunluğu genç seçmenlerden oluşan kullanıcılar, çeşitli etkinlikler organize edebilmiş ve bu etkinliklere katılım sağlayabilmek için ihtiyaç duyulan sosyal etkileşim ve paylaşım ortamı yaratılmıştır.

Barrack H. Obama’nın çevrimiçi kampanya stratejisinin merkezinde genç seçmenlerin siyasal alana dikkatlerinin çekilmesi yanı sıra izleyici olmak yerine kampanyanın öznesi olabilme imkânı veren paylaşım ve etkileşime dayalı medya ortamının yaratılması bulunmaktadır. Böylece geleneksel olarak apolitik oluşlarıyla tanımlanan genç seçmen kitlesinin kampanya iletişiminde aktif rol almasının önünü açan yeni bir 
evreye geçilmiştir. Genç seçmenler artık sadece bir izleyici ya da dinleyici değil aynı zamanda kampanya sürecinin bir parçası haline gelerek "Facebook, Twitter, Friendfeed ve YouTube" gibi sosyal medya kanallarını da içine alacak şekilde kampanya iletişimini pek çok mecraya yaymışlardır.

2008 ABD başkanlık seçim kampanyasında çevrimiçi kanalların yanı sıra çevrimdışı olarak tanımlanan geleneksel kitle iletişim araçları da -gazeteler, dergiler, radyo, televizyon- kullanılmaya devam etmiştir. Ancak kampanya sürecinde iletişim, üniversiteler ya da üniversitelerin bulunduğu büyük kentler üzerinde yoğunlaştığı için kentlerdeki tüm platformlarda kampanya için kurulan web sitelerinin reklamları bulunmaktadır. Genç seçmenlerin ilgisini çekecek tüm yolların denendiği kampanya sürecinde gençler arasında oldukça popüler bir oyun konsolu olan " $X$-Box" esas alınarak "Beyaz Saray Yarışı” isimli bir oyun bile tasarlanmıştır. Kampanyanın ekonomik kaynaklarını çeşitlendirecek şekilde web siteleri üzerinden güncellenen bir bağış sistemi geliştirilmiş ve genç seçmenlerin fiilen içinde yer aldıkları kampanyaya aynı zamanda bağışçı olabilmelerinin yolu açılmıştır. Ekonomik kaynakların arttırılması ihtiyacından ortaya çıkan ve geleneksel bağış kampanyasına paralel olacak şekilde çevrimiçi bağış kampanyası düzenlenmesi sayesinde kaynakların çeşitlenmesi sağlanmıştır. Kampanya boyunca "viral pazarlama" olarak adlandırılan ve kaynak tarafından iletilmesi arzu edilen mesajların hedef kitleye kulaktan kulağa yayılmasına dayalı yöntem, sosyal medya kanalları kullanılarak etkili bir şekilde uygulanmıştır. Bu maksatla "Super Obama Girls" adıyla bir video dizisi oluşturularak "YouTube" üzerinden yayınlanmış ve bu videolar, toplamda on beş milyon gibi çok yüksek tekil izlenme sayılarına ulaşmıştır. ${ }^{28}$

Barrack H. Obama'nın çevrimiçi kampanya stratejisini belirleyen Chris Hughes; "Facebook, Twitter, Friendfeed, YouTube" gibi mecraların yanı sira "MySpace, Digg, Blackplanet, Linkedın, AsianAve, MiGente ve Glee" gibi görece daha az tanınan dijital mecraları da kampanya maksatları için kullanmıştır. ${ }^{29}$

ABD merkezli araştırma şirketi “Pew Research Center" tarafından yapılan inceleme; Amerikan seçmenlerinin yaklaşık \%46’sının 2008 kampanyasılla ilgili haberlere katkıda bulunmak ya da başkalarını harekete geçirmek için en az bir kere internet sitesini kullandığ 1 , elektronik posta ya da kısa mesaj gönderdiğini göstermektedir. Diğer yandan; seçmenlerin \%35’i bir önceki seçime göre üç kat daha fazla kampanya videoları izlemek için çevrimiçi olduğu bir ortamda” gerçekleştirilmiştir. Kampanya boyunca internet kullanıcılarının \%74'ü seçim kampanyasına katılmak ya da kampanya hakkında haber alabilmek için çevrimiçi olmuştur. Bu oran ABD'de yaşayan tüm yetişkin nüfusun yaklaşı \%55'ine tekabül etmekte ve Amerikan tarihinde ilk kez oy kullanma yaşına erişmiş toplam nüfusun yarısından fazlasının seçim kampanyası süreci boyunca yoğun bir şekilde internet kullandığını göstermektedir. Tablo 2, 3 ve 4'te 2008 yılı ABD Başkanlık seçim kampanyalarında seçmenlerin çevrimi-

28 Brian Braiker, “Obama Girl’s Latest Viral Vid”, erişim 21 Nisan, 2020. https://www.newsweek.com/obama-gir1s-latest-viral-vid-86593.

29 Scott John Hammond, Robert North Roberts ve Valerie A. Sulfaro, Campaigning for President in America 1788-2016, California: Greenwood, 2016, s.158. 
çi kullanıcı göstergeleriyle birlikte seçmenlerin son dört seçim döneminde (19962000-2004-2008), siyasal haber alma maksadıla çevrimiçi olma oranları ve nihayet 2008 Başkanlık seçim kampanya döneminde başkanlık için yarışan iki adayın sosyal medya etkinliklerine ait nicel veriler bulunmaktadır. ${ }^{30}$

Tablo 2. ABD 2008 Başkanlık Seçimleri Çevrimiçi Kullanıcı Göstergeleri

\begin{tabular}{|l|c|}
\hline \multicolumn{1}{|c|}{ İnternet Kullanıcılarının Çevrimiçi Olma Nedeni } & Yüzdelik Oran \\
\hline Kampanya ve politik gelişmeler hakkında bilgi ya da haber almak & $\% 60$ \\
\hline $\begin{array}{l}\text { Siyasal gelişmelerle ilgili başkalarıyla internet aracılığıyla etkileşime } \\
\text { geçmek }\end{array}$ & $\% 38$ \\
\hline E-posta ya da kısa mesaj kullanarak kampanya bilgilerini yaymak & $\% 59$ \\
\hline
\end{tabular}

Tablo 3. Siyasal Haber Alma Maksadıyla Yillara Göre Artan Çevrimiçi Olma Oranları

\begin{tabular}{|l|c|c|c|c|}
\hline \multirow{2}{*}{\multicolumn{1}{|c|}{ Göstergeler }} & \multicolumn{4}{c|}{ Yillar } \\
\cline { 2 - 5 } & 1996 & 2000 & 2004 & 2008 \\
\hline Tüm nüfusa göre & $\% 4$ & $\% 18$ & $\% 29$ & $\% 44$ \\
\hline İnternet kullanıcı sayısına göre & $\% 22$ & $\% 33$ & $\% 52$ & $\% 60$ \\
\hline
\end{tabular}

Tablo 4. Barack Obama ve John McCaine Ait Sosyal Medya Etkinlik Göstergeleri

\begin{tabular}{|c|c|c|c|c|}
\hline Başkan Adayı & Facebook & Twitter & YouTube & Paylaşılan Video Sayısı \\
\hline Barrack H. Obama & 2.000 .000 & 112.000 & 115.000 & 1.800 \\
\hline John McCain & 600.000 & 4.600 & 12.000 & 300 \\
\hline
\end{tabular}

2008 başkanlık seçimleri, \%44 oranıyla her on internet kullanıcısından altısına tekabül edecek şekilde seçmenlerin politik haber alabilmek maksadıyla çevrimiçi olduğunu göstermiştir. İnternet kullanıcılarının \%12'si siyasal haber alabilmek için günde en az bir kez, \%7'si ise gün boyu bir kereden fazla çevrimiçi olacak şekilde ve ülkedeki toplam nüfusun yaklaşık beşte birine tekabül eden oranda çevrimiçi olmuştur. Böylece siyasal haber alma ihtiyacının giderilmesi maksadıyla internete bağlanma oranları 2000 yılı başkanlık seçimlerine göre iki katına çıkmıştır.

\section{Sonuç}

İletişim alanında etkisini gösteren teknolojik yenilenmelere rağmen toplumun büyük bir çoğunluğu tarafından kitle iletişim araçları bilgiye ulaşmanın yanı sıra eğlence aracı olarak kullanılmaya devam edilmektedir. ${ }^{31}$ Gazete, radyo ve televizyondan oluşan geleneksel kitle iletişim araçlarının sahip olduğu güçlü etki, günümüzde

30 Aaron Smith, “The Internet's Role in Campaign 2008”, erişim 1 Nisan, 2020. https://www.pewresearch.org/ internet/2009/04/15/the-internets-role-in-campaign-2008/.

31 Kitle iletişim araçları ve buradaki uygulamaların fazla sayıda kullanıcıya ulaşma süreleri de giderek kısalmaktadır. Teknolojinin hızlı gelişimi, internetin 50 milyon kişiye 4 yılda ulaşmasını sağlamış, Facebook uygulamasının 3,5 yılda ve Angry Birds oyununun sadece 35 günde 50 milyon kişinin kullanmasını sağlamıştır. Instagram uygulaması ise 4 yılda 300 milyon kullanıcı sayısına ulaşmıştır; Ayrıntı için bkz. Bilgi Teknolojileri ve İletişim Kurumu, "Bakan Yardımcısı Sayan: Ar-Ge ve İnovasyon Rekabetin İki Önemli Aracı", erişim 16 Mayıs, 2019, https://www.btk.gov.tr/haberler/bakan-yardimcisi-sayan-ar-ge-ve-inovasyon-rekabetin-iki-onemli-araci. 
yerini dijital iletişim platformları olarak adlandırılan internete ve sosyal paylaşım ağlarına bırakmaktadır. Dahası pek çok geleneksel kitle iletişim araçları dijital iletişim platformlarında kurumsal hesaplar oluşturarak, haber, bilgi ya da içerik paylaşımlarını artan oranda dijital iletişim mecralarına kaydırmaktadır. Dijital iletişim araçları, geleneksel kitle iletişim mecralarına nispeten çeşitli avantaj ve dezavantajlara sahiptir. Ancak günümüzde gazetelerin tiraj sayıları ya da televizyon izlenme oranlarına bakıldığında dikkat çekici düşüş olduğu gözlenmektedir. ${ }^{32}$

Diğer yandan kitle iletişim teknolojilerinde kaydedilen gelişmeler ve yeni iletişim ortamlarının yaygınlaşması, siyasal iletişim faaliyetlerinde gözle görülür değişime neden olmaktadır. Sözgelimi siyasal aktör ile seçmen arasında kurulması arzu edilen etkileşimi güçlendirmek üzere kurgulanan ikna edici iletişim faaliyeti olarak seçim kampanyaları ve siyasal aktörler arasındaki rekabetin yönü üzerinde belirleyici olmaktadır. Çalışmanın örneklemi olarak incelenen 1952 yılı başkanlık seçimlerinde Dwight Eisenhower'in seçmen nezdinde elde ettiği itibar, ilk bakışta bir savaş kahramanı olarak ordu hizmetlerine bağlanabilir ancak seçim kampanyasında benimsenen strateji dâhilinde televizyonu kullanması nedeniyle siyasal reklamcılık bağlamında öncü olarak nitelendirilmesine neden olmuştur. Kampanya direktörü Rosser Reeves tarafından kurgulanan televizyon spotları sayesinde seçmen nezdinde kazanılan dürüst ve açık sözlü başkan adayı imajı inşa edilmiştir. Demokrat aday Adlai Stevenson, televizyona olan mesafesi ve pek de başarılı sayılamayacak ekran performansı seçmen nezdinde başarısız olmuştur. Sonuç olarak gerek başkanlık kampanya süreci gerekse seçim sonuçları bakımından 1952 seçimleri, siyasal aktör ile seçmen arasında kurulan etkileşim bakımından televizyonun katkısını büyük oranda teslim etmektedir.

21. yüzyılın başından itibaren internet kullanım olanakları ve internet kullanıcı sayılarında görülen büyük sıçramalar nedeniyle geleneksel kitle iletişim araçlarının okunma, dinlenme ya da izlenme oranlarında giderek azalan etkiye neden olmuş ancak seçim kampanyaları ve siyasal aktörler arasındaki rekabetin yönü üzerinde belirleyici rolünü giderek arttırmıştır. Çalışmanın ikinci örneklemi olarak ele alınan Barack H. Obama’nın 2008 yılı seçim kampanya stratejisi dikkate alındığında, adayın kampanya stratejisini büyük oranda değişimden yana tavır gösteren genç seçmenler üzerine planladığ olarak kullandığı gözlenmiştir. ABD 2008 Başkanlık Seçim sonuçlarına bakıldığında Barack H. Obama’nın 18-29 yaş genç seçmenlerin \%66’sının oyunu aldığı, rakibi Joseph McCain'in ise aynı seçmen kitlesinin ancak \%31'inin oyunu alabildiği görülmektedir. ${ }^{33}$ Böylece 2008 seçimleri, genç seçmen kitlesine hitap eden ve onlara

32 Sözgelimi 03 Eylül 2012 - 09 Eylül 2012 haftası arasında Türkiye’de toplam satılan gazete sayısı 4.568.383 iken, 03 Eylül 2018 - 09 Eylül 2018 haftası arasında satılan gazete sayısı 2.797 .567 olmuştur. Ayrıntı için bkz. MedyaTava, “Tiraj”, erişim 16 Mayıs, 2020, https://www.medyatava.com/tiraj. Aynı tarihler arasında artan internet kullanımı, insanların eskisi kadar gazete satın almamalarının nedeni olarak gösterilmektedir. Diğer yandan televizyon izleme süreleri üzerine yapılan araştırma sonuçlarına göre; televizyon izleme sürelerinin 2006 yılında günlük ortalama 5 saat 8 dakika, 2009 yılında 4 saat 23 dakika, 2012 yılında 3 saat 54 dakika, 2018 yılındaysa 3 saat 34 dakika olarak kaydederek istikrarlı bir düşüşolduğunu göstermektedir. Radyo ve Televizyon Üst Kurulu, “Televizyon İzleme Eğilimleri Araştırması 2018”, erişim 19 Mayıs, 2019.

33 Tom Rosentiel, "Young Voters in the 2008 Election”, erişim 15 May1s, 2019, https://www.pewresearch. 
yönelik kampanya düzenleyen adayların seçimlerde öne çıktığı kadar dijital iletişim platformlarını etkili bir şekilde kullanan aday ve kampanyaların avantajlarına dikkat çekmiştir. Zira dijital iletişim platformlarının kullanıcı sayılarındaki artışa bakıldığında, bu platformların siyasa aktör ile seçmen arasındaki iletişimi tamamlayacak şekilde yaygınlık kazandı̆̆ 1 görülmektedir. ${ }^{34}$

\section{Kaynakça}

AdAge. "Reeves, Rosser (1910-1984)". Erişim 16 Nisan, 2020. https://adage.com/ article/adage-encyclopedia/reeves-rosser-1910-1984/98848.

Aristoteles. Retorik. Çev., Mehmet H. Doğan. İstanbul: Yapı Kredi Yayınları, 1995.

Atiker, Erhan. Modernizm ve Kitle Toplumu. Ankara: Vadi Yayınları, 1998.

Aydoğan, Filiz. "Tüketim Kültürünün Gölgesinde Kentler”. Marmara Üniversitesi İktisadi ve İdari Bilimler Dergisi. 27/2 (2009): 203-215.

Bayrak, Halil. "2019 Türkiye İnternet Kullanım ve Sosyal Medya İstatistikleri”. Erişim 15 Mayıs, 2019. https://dijilopedi.com/2019-turkiye-internet-kullanimve-sosyal-medya-istatistikleri/.

Berman, Marshall. Katı Olan Her Şey Buharlaşıyor. Çev., Ümit Altuğ ve Bülent Peker. İstanbul: İletişim Yayınları, 2017.

Bilgi Teknolojileri ve İletişim Kurumu. "Bakan Yardımcısı Sayan: Ar-Ge ve İnovasyon Rekabetin İki Önemli Aracı”. Erişim 16 Mayıs, 2019. https://www.btk.gov.tr/ haberler/bakan-yardimcisi-sayan-ar-ge-ve-inovasyon-rekabetin-iki-onemliaraci.

Bongrand, Michel. Politikada Pazarlama. Çev., Fatoş Ersoy. İstanbul: İletişim Yayınları, 1992.

Braiker, Brian. “Obama Girl's Latest Viral Vid”. Erişim 21 Nisan, 2020. https://www. newsweek.com/obama-girls-latest-viral-vid-86593.

Dillard, James Price ve Lijiang Shen. The Sage Handbook of Persuasion. California: Sage Publications, 2012.

Erdoğan, İrfan ve Korkmaz Alemdar. Öteki Kuram. Ankara: Erk Yayıncılık, 2005.

Giddens, Anthony. Modernliğin Sonuçları. Çev., Erol Kuşdil. İstanbul: Ayrıntı Yayınları, 2018.

Hall, Richard. H. Sociology Of Work. California: A Sage Publications Company, 1994. Hammond, Scott John, Robert North Roberts ve Valerie A. Sulfaro. Campaigning for President in America 1788-2016, California: Greenwood, 2016.

org/2008/11/13/young-voters-in-the-2008-election/.

34 2018-2019 yıllarında yapılan araştırma sonuçlarına göre; 2018 yılında Türkiye’de 51 milyon aktif sosyal medya kullanıcı bulunmaktayken, bu sayı 2019 yılında ülke nüfusunun \%63'ünü oluşturacak hacimde toplam 52 milyona ulaşmıştır; Ayrıntı için bkz. Cengizhan Salih, "2018 Türkiye İnternet Kullanım ve Sosyal Medya İstatistikleri”, erişim 15 Mayıs, 2019, https://dijilopedi.com/2018-turkiye-internet-kullanim-ve-sosyal-medya-istatistikleri; Halil Bayrak, "2019 Türkiye İnternet Kullanım ve Sosyal Medya İstatistikleri“, erişim 15 Mayıs, 2019, https:// dijilopedi.com/2019-turkiye-internet-kullanim-ve-sosyal-medya-istatistikleri/. Günümüzde sosyal medya mecralarını seçmenleriyle iletişim kurmak için kullanan siyasal aktörlerin sayısı azımsanmayacak oranlara ulaşmıştır. Bu minvalde sözgelimi gündemdeki bir olay, bir anma ya da bilgi paylaşımı için siyasal aktörler sosyal medya mecralarını kullanmaktadır. 
Heyer, Paul. The Medium and the Magician. Maryland: Rowman\& Littlefield Publishers, 2005.

Hollitz, John E. "Eisenhower and the Admen: The Television "Spot" Campaign of 1952". The Wisconsin Magazine of History. 66/1 (1982): 25-39.

Jones, Jean. G. ve Herbert W. Simons. Persuasion in Society. New York: Routledge, 2017.

Kongar, Emre. Toplumsal Değişme Kuramları ve Türkiye Gerçeği. İstanbul: Remzi Kitabevi, 1981.

Lilleker, Darren. G. Siyasal İletişim. Çev., Könül Mammadlı. İstanbul: Kaknüs Yayınları, 2013.

Marx, Karl ve Friedrich Engels. Komünist Manifesto. Çev., Levent Kavas. İstanbul: İthaki Yayınları, 2011.

MedyaTava. “Tiraj”. Erişim 16 Mayıs, 2020. https://www.medyatava.com/tiraj.

O'Keefe, Daniel. J. Persuasion: Theory and Research. California: Sage Publications, 2002.

Öztürk, Gülcennet. "Bir Propaganda Aracı Olarak Radyo”. Abant Kültürel Araştırmalar Dergisi. 2/3 (2017): 157-174.

Perloff, Richard. M. The Dynamics of Persuasion. New Jersey: Lawrence Erlbaum, 2010.

Platon. Gorgias. Çev., Reyan Erben. İstanbul: M.E.B. Yayınları, 1997.

Radyo ve Televizyon Üst Kurulu. “Televizyon İzleme Eğilimleri Araştırması 2018”. Erişim 19 Mayıs, 2019. https://www.rtuk.gov.tr/assets/Icerik/AltSiteler/ televizyonizlemeegilimleriarastirmasi2018.pdf.

Rosentiel, Tom. "Young Voters in the 2008 Election". Erişim 15 Mayıs, 2019. https:// www.pewresearch.org/2008/11/13/young-voters-in-the-2008-election/.

Sadakaoğlu, Mustafa C. "Yeni Türk Sinemasında Modern Melodram Geleneksel Söylem”. Motif Akademi Halkbilimi Dergisi. 12/28 (2019): 1183-1200.

Salih, Cengizhan. “2018 Türkiye İnternet Kullanım ve Sosyal Medya İstatistikleri”. Erişim 15 Mayıs, 2019. https://dijilopedi.com/2018-turkiye-internet-kullanimve-sosyal-medya-istatistikleri.

Sander, Oral. Siyasi Tarih. İstanbul: İmge Yayınevi, 2001.

Smith, Aaron. “The Internet's Role in Campaign 2008”. Erişim 1 Nisan, 2020. https://www.pewresearch.org/internet/2009/04/15/the-internets-role-incampaign-2008/.

Thoreau, Henry David. Walden and Other Writings. New York: Bantham Books, 1962.

Topuz, Hifzı. Siyasal Reklamcılık. İstanbul: Cem Yayınevi, 1991.

Trent, Judith. S. ve Robert V. Friedenberg. Political Campaign Communication: Principles and Practices. London: Penguin Books, 2000.

Uztuğ, Ferruh. Siyasal Marka Seçim Kampanyaları ve Aday Imajı. Ankara: Mediacat Yayınları, 1999. 
Uzun, Ruhdan. Iletişim Kuramları. Haz., Erkan Yüksel. Eskişehir: Anadolu Üniversitesi Yayınları, 2013.

Ülgener, Sabri Fehmi. Zihniyet ve Din. İstanbul: Der Yayınları, 1981.

Yaylagül, Levent. Kitle İletişim Kuramları. Ankara: Dipnot Yayınları, 2018.

Yüksel, Ahmet Haluk. İkna Edici İletişim. Haz., Mine Oyman. Eskişehir: Anadolu Üniversitesi Yayınları, 2014.

Zeybek, Burcu. Siyasal Reklam İkna ve Retorik. İstanbul: Beta Yayınc1l1k, 2016.

Weber, Max. Protestan Ahlakı ve Kapitalizmin Ruhu. Çev., Mehmet Ökten. Ankara: Tutku Yayınevi, 2014. 
İNSAN\&İNSAN, Y11/Year 7, Say1/Issue 25, Yaz/Summer 2020, 29-45

DOI: https://doi.org/10.29224/insanveinsan.736181

\title{
The 1952 and 2008 US Presidential Election Campaigns in terms of Traditional and Digital Mass Communication
}

\author{
MUSTAFA C. SADAKAOĞLU
}

\author{
ÖZGÜR EMEK KORKMAZ
}

\begin{abstract}
The modern individual was defined as voter after the emergence of consent-based regimes and was exposed to persuasive political communication messages from the mass media. Mass media is very important for the voter to take an attitude towards the messages he/she is exposed to. Although media habits have changed over the years, from traditional mass media to digital mass media, the strong interaction between media and democracy. Nowadays, political actors use various digital communication tools extensively as well as traditional mass media such as newspaper, radio and television. Television was used for the first time in the US presidential elections of 1952 and the US presidential elections of 2008 which used the digital communication tool for the first time. In this reason, this study based on the interaction between the concepts of media and democracy, the data obtained from the election campaigns determined as the sample of the study are examined.
\end{abstract}

Keywords: Democracy, Political communication, Political advertising, Television, Social media. 